\title{
PRÁTICAS LEITORAS E INFORMACIONAIS NAS BIBLIOTECAS COMUNITÁRIAS EM REDE DA RELEITURA -PE ${ }^{1}$
}

\author{
READING AND INFORMATION PRACTICES IN COMMUNITY LIBRARIES IN NETWORK - \\ RELEITURA -PE \\ PRÁCTICAS LECTURALES E INFORMACIONALES EN LAS BIBLIOTECAS COMUNITARIAS \\ EN RED DE LA RELEITURA -PE
}

${ }^{1}$ Mariana de Souza Alves, ${ }^{1}$ Anna Elizabeth Galvão Coutinho Correia, ${ }^{1}$ Diego Andres Salcedo ${ }^{1}$ Universidade Federal de Pernambuco

\section{Correspondência}

${ }^{1}$ Mariana de Souza Alves

Universidade Federal de Pernambuco

Recife, PE - Brasil.

Email: mdsa24@gmail.com

ORCID: http://orcid.org/0000-0002-3452-9629

Submetido em: 07/08/2017

Aceito em: 23/10/2017

Publicado em: 23/11/2017

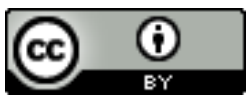

JITA: DC. Public libraries.

\footnotetext{
${ }^{1}$ Trabalho originalmente apresentado como dissertação apresentada ao Curso de Mestrado do Programa de PósGraduação em Ciência da Informação do Centro de Artes e Comunicação, da Universidade Federal de Pernambuco.
} 
RESUMO: Analisa as práticas leitoras e informacionais existentes em quatro bibliotecas comunitárias da Releitura-PE, a partir de dois pilares: das ações que ela realiza e das condutas/vivências/sentimentos dos sujeitos envolvidos com essas bibliotecas. Utiliza como embasamento teórico uma reflexão que busca discutir o conceito de leitura de maneira ampla, bem como sua relação com os conceitos de mediação e apropriação da informação e esboça considerações sobre o conceito de informação e suas implicações com as práticas informacionais. Realiza ainda explanação conceitual sobre bibliotecas comunitárias, buscando compreender as singularidades dessa tipologia de bibliotecas, bem como apresenta a Releitura. Do ponto de vista metodológico, realiza um estudo de caráter bibliográfico aliado a uma investigação empírica de coleta de informações acerca das bibliotecas comunitárias e coleta de depoimentos dos sujeitos que fazem parte dessas bibliotecas, tais como gestores, mediadores de leitura e interagentes, por meio de entrevistas semiestruturadas, as quais foram analisadas e categorizadas por meio da técnica de Análise de Conteúdo. Conclui que as práticas leitoras e informacionais dos sujeitos são múltiplas e se revelam tanto individualmente, nas maneiras de ler e de se informar, como coletivamente, nas seguintes práticas: gestão, organização e incidência política; formação e capacitação da equipe; comunicação e divulgação das ações; mediação de leitura e ações culturais; articulação com entidades locais e interação com a biblioteca. A biblioteca, por sua vez, foi considerada um espaço vivo, local de convivência, leitura, aprendizado e lazer, além de um instrumento de politização e desenvolvimento da cidadania e da autonomia dos sujeitos.

PALAVRAS-CHAVE: Biblioteca comunitária. Leitura. Informação. Releitura -PE.

ABSTRACT: It analyzes the existing reading and information practices in four community libraries of the Releitura-PE, based on two pillars: the actions it performs and the behaviors/ experiences/feelings of the subjects involved with these libraries. It uses as a theoretical basis a reflection that seeks to discuss the concept of reading in a broad way, as well as its relationship with the concepts of mediation and appropriation of information and sketches considerations about the concept of information and its implications with informational practices. It also elaborates conceptual explanation about community libraries, seeking to understand the singularities of this typology of libraries, as well as presents the Releitura-PE. From the methodological point of view, it carries out a bibliographic study, together with an empirical investigation of the collection of information about community libraries and the collection of testimonies of the individuals that are part of these libraries, such as managers, reading mediators and interactors, through semi-structured interviews, which were analyzed and categorized using the Content Analysis, technique. It concludes that the reader's and informational practices of the subjects are multiple and are revealed individually, in the ways of reading and informing themselves, as well as collectively, in the following practices: management, organization and political incidence; training and qualification of the team; communication and dissemination of actions; mediation of reading and cultural actions; Articulation with local entities and interaction with the library. The library, in turn, was considered a living space, a place of coexistence, reading, learning and leisure, as well as an instrument of politicization and development of citizenship and autonomy of the individuals.

KEYWORDS: Community library. Reading. Information. Releitura -PE.

RESUMEN: Se analiza las prácticas lectoras e informativas existentes en cuatro bibliotecas comunitarias de la Releitura-PE, a partir de dos pilares: de las acciones que ella realiza y de las conductas/ vivencias/sentimientos de los sujetos involucrados en esas bibliotecas. Utiliza como base teórica una reflexión que busca discutir el concepto de lectura de manera amplia, así como su relación con los conceptos de mediación y apropiación de la información y esboza consideraciones sobre el concepto de información y sus implicaciones con las prácticas informacionales. Se realiza una explicación conceptual sobre bibliotecas comunitarias, buscando comprender las singularidades de esa tipología de bibliotecas, así como presenta la Releitura. Desde el punto de vista metodológico, realiza un estudio de carácter bibliográfico aliado a una investigación empírica de recolección de informaciones acerca de las bibliotecas comunitarias y recolección de testimonios de los sujetos que forman parte de esas bibliotecas, tales como gestores, mediadores de lectura e interagentes, por medio de entrevistas semiestructuradas, las cuales fueron analizadas y categorizadas por medio de la técnica de Análisis de Contenido. Concluye que las prácticas lectoras e informacionales de los sujetos son múltiples y se revelan tanto individualmente, en las maneras de leer y de informarse, como colectivamente, en las siguientes prácticas: gestión, organización e incidencia política; formación y capacitación del equipo; comunicación y difusión de las acciones; mediación de lectura y acciones culturales; articulación con entidades locales e interacción con la biblioteca. La biblioteca, por su parte, fue considerada un espacio vivo, local de convivencia, lectura, aprendizaje y ocio, además de un instrumento de politización y desarrollo de la ciudadanía y de la autonomía de los sujetos.

PALABRAS CLAVE: Biblioteca comunitaria. Lectura. Información. Releitura -PE.

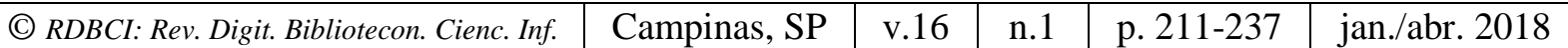




\section{PONDO A LINHA NA AGULHA: considerações iniciais}

As bibliotecas comunitárias são espaços que têm alcançado destaque social pela forma com a qual gerenciam e promovem suas ações em prol do acesso à leitura, informação e cultura das classes menos favorecidas. Surgem geralmente em bairros marginalizados por inciativa da própria população de forma solidária e voluntária, na busca de suprir as demandas de leitura desses locais, além de ser um espaço alternativo à inoperância das bibliotecas escolares e distância das bibliotecas públicas em relação aos bairros mais periféricos.

Na Região Metropolitana do Recife (RMR), em Pernambuco, o grupo de bibliotecas comunitárias Releitura-PE vem desenvolvendo um trabalho relevante de formação de leitores em comunidades periféricas. Criada em 2007, essa articulação conta hoje com sete bibliotecas e tem a missão de revigorar e qualificar suas bibliotecas integrantes, com o fim de democratizar o acesso ao livro e à cultura escrita, tendo como princípio a leitura como um direito humano.

Por isso, para contribuir com a ampliação da visibilidade dessas experiências, bem como compreender e caracterizar as práticas informacionais e leitoras das bibliotecas comunitárias, de forma a descobrir o que é produzido e vivenciado nesses espaços a partir da interação com a informação e com a leitura realizamos este estudo na Releitura por ser um coletivo de destaque em termos de tempo de atuação e articulação político-social que luta e resiste diariamente em busca de comunidades mais leitoras e informadas.

\section{PRÁtICAS LEITORAS}

Propomos para esta reflexão teórica uma discussão que parte do pressuposto de que a apropriação informacional é adquirida por meio de um processo de mediação cuja base é a leitura. Em virtude disso, os sujeitos constroem um conjunto de práticas informacionais e leitoras por meio de processo dialógico e interacional nas ações de busca, uso e compartilhamento de informações numa perspectiva sociocontextual, bem como se apropriam de fontes, atribuindo sentidos, sentimentos e vivências às suas ações.

Concordamos com Almeida Júnior (2007) quando afirma que a leitura é peça fundamental para a existência da informação. Pois é a partir da leitura que ocorre a apropriação informacional, ou seja, é no ato da leitura que a informação se concretiza. Sem uso da leitura, é impossível prover sentido às ações desenvolvidas pela Biblioteconomia e Ciência da Informação, pois ambas possuem a leitura como base de sustentação (ALMEIDA JÚNIOR, 2007).

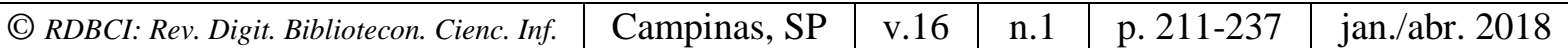


Porém, a leitura aqui deve ser entendida em sentido amplo e, portanto, na sua interação com outras linguagens, e não apenas com o texto escrito, como ocorre frequentemente. Dessa forma, leitura, aqui, para além de uma decodificação mecânica das letras, é compreendida como um movimento sensorial, emocional e fisiológico que envolve diversas instâncias do saber, do sentir e do ser (MARTINS, 1997). Assim como Paulo Freire (2011), que defende a leitura do mundo, ao invés de apenas a leitura da palavra, consideramos que a formação de leitores exige uma dinâmica inclusiva que abarque todos os tipos de leitura, não apenas a do texto escrito, e que compreenda a realidade e o contexto que permeiam essas linguagens. Logo, a leitura não diz respeito somente aos letrados, a leitura das imagens, dos símbolos, das cores, da música, da dramaturgia, do filme, das conversas também são elementos que fazem parte da formação leitora.

Desse modo, diversas experiências envolvem o ato de ler, que vão desde um teor mais pragmático e utilitário até uma vertente mais social e imaginativa. Conforme a antropóloga francesa Michele Petit (2008), a leitura pode contribuir em diversos aspectos como acesso ao conhecimento, à instrução, apropriação da língua, construção de si mesmo, de uma identidade singular, extensão do horizonte de referências e desenvolvimento de novas formas de sociabilidade e da autonomia perante os discursos dominantes.

A leitura literária, por sua vez, é uma forma primorosa de adentrar no universo da fabulação e do encantamento e, consequentemente, de adquirir habilidades mais instrumentais. Cândido (2012, p. 23) conceitua literatura como "todas as criações de toque poético, ficcional ou dramático em todos os níveis de uma sociedade, em todos os tipos de cultura, desde o que chamamos folclore, lenda, até as formas mais complexas e difíceis da produção escrita das grandes civilizações". Tal manifestação está presente do analfabeto ao erudito, do causo à HQ, e, sendo assim, corresponde ao uso da palavra para a criação de mundos ou um sentimento de mundo (COSSON, 2014), cuja presença é imprescindível a qualquer povo.

Acreditamos, portanto, que ler é um direito e que seu poder de transformação pode ajudar as pessoas a se entenderem melhor enquanto sujeitos cidadãos e atores da sua própria história. Como Riter (2009, p.35) nos diz, ser leitor faz diferença porque nos permite construir novos sentimentos e experiências, "é possibilidade de construção de um ser humano melhor, mais crítico, mais sensível; alguém capaz de se colocar no lugar do outro; alguém mais imaginativo e sonhador; alguém um pouco mais liberto dos tantos preconceitos que a sociedade vai impondo-nos a cada dia".

Entretanto, ao se tratar de um espaço informacional de formação de leitores, cabe destacar a figura de outro importante elemento no processo de mediação de leitura, que é o mediador. Ele é responsável por colaborar na construção de um leitor mais maduro no movimento interacional que relaciona obra-leitor, tendo "o encargo de encaminhar o leitor à

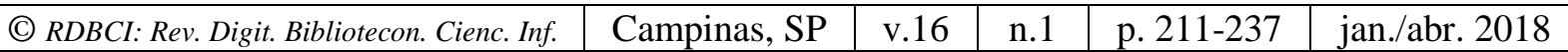


novas descobertas e aventuras" (ALMEIDA JÚNIOR; BORTOLIN, 2008, p.3). Isso não quer dizer que sejam mediadores apenas os sujeitos que trabalham na biblioteca, mas todos aqueles que trocam, indicam, comentam e sugerem leituras entre si.

Lembramos também que todo ato de mediação pressupõe uma interferência. Tal interferência que pode ser realizada pelo profissional da informação ou não vai ao encontro da ideia da suposta neutralidade desse profissional, pois não existe mediação imparcial, mas, pelo contrário, toda interferência é salutar, desde que não seja confundida com manipulação, embora esta possa existir de modo inconsciente (ALMEIDA JÚNIOR, 2007).

A mediação da leitura se constitui, desse modo, como uma forma de apresentar e de estimular a leitura de uma obra. O mediador de leitura tem a função de possibilitar experiências de apreciação da obra, de fruição estética, que aproximem as relações entre a obra e o leitor, ampliando seu universo de leitura. Ele é também o ator que vai facilitar e conduzir o acesso aos textos, quando estes ainda são estranhos ao leitor. Não é papel do mediador impor suas impressões sobre a obra, mas estimular e despertar o interesse do leitor por ela (RITER, 2009; NEITZEL; BRIDON; WEISS, 2016).

Sendo assim, o lugar da leitura nas bibliotecas organiza-se de maneira singular e estruturante, como um modo de formação por meio da garantia do direito à leitura, sobretudo à leitura literária. Em uma perspectiva ampla, a leitura é aqui apresentada como um mote para a fruição estética de uma obra artística, bem como para a educação cidadã e humana, além do enfretamento das condições de exclusão social.

Com isso, foca-se na importância do ato de ler e da produção de sentidos por meio da leitura literária, a qual é sempre envolta de uma rede de mediações e de um repertório construído pelo leitor. As maneiras e os motivos de ler são plurais e nem sempre convergem. Eis, então, as infinitas possibilidades de interpretação propiciadas pela obra.

Portanto, as maneiras singulares de ler, as construções derivadas da leitura e as instâncias que envolvem a mediação da leitura, convergem nas práticas de leitura e informação que são as atividades, sensações, os modos de ler dos sujeitos com fins de uso estético ou utilitário desde que façam sentido para elas. Essas práticas promovem por meio do uso de informações a formação de leitores e consequentemente abertura de novos caminhos para a vida desses sujeitos.

\section{PRÁtICAS INFORMACIONAIS}

A informação está imbricada em todas as práticas sociais, como algo que precisa do sujeito para atribuir sentido, e cujo contexto é vital para seu significado. Podemos dizer que todos os seres humanos usam e interagem com a informação, cada qual com suas

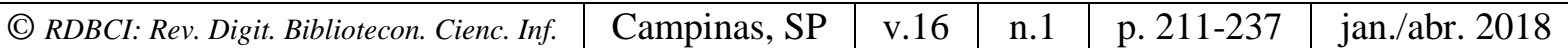


peculiaridades. Todas as pessoas precisam de informação para realizar suas práticas sociais, sejam elas pessoais, recreativas, profissionais ou acadêmicas. Sendo assim, as informações estão inseridas em todas as ações diárias, pois buscam-se informações cotidianamente para realizar diversas atividades (CUNHA; AMARAL; DANTAS, 2015).

Procuramos delinear, incialmente, o conceito de informação como um fenômeno que se apresenta sob três faces - material, subjetiva e social - a qual os sujeitos constroem mediante ações cognitivas e interacionais com outros sujeitos com autonomia para perceber o que é informativo para ele ou para o grupo. Em seguida, para fundamentar o conceito de práticas informacionais, fizemos uma breve introdução aos estudos de usuários e apresentamos as práticas informacionais como uma tendência emergente deste campo.

Em termos terminológicos, a palavra informação tem origem latina, do verbo informare, traduzida para o grego como informatio e informo, que significa dar forma a algo, construir uma ideia, moldar a matéria. Na Idade Média, o termo foi usado no sentido ontológico e epistemológico de dar forma a alguma coisa e no sentido pedagógico de instruir (CAPURRO; HJØRLAND, 2007).

Na transição da Idade Média para a Idade Moderna, o uso do termo informação no sentido de dar forma à matéria passa a ser empregado com a denotação de comunicar alguma coisa a alguém, sendo considerado, portanto, algo intangível. Todavia, essa abstração do conceito de informação deixou de existir até o surgimento da Teoria da Informação na metade do século XX (CAPURRO; HJØRLAND, 2007), teoria esta que influenciou diretamente as primeiras formulações acerca do conceito de informação na CI.

A Teoria Matemática da Comunicação, ou, como ficou conhecida, a Teoria da Informação se apresenta como uma concepção física da informação ao concebê-la como um elemento que pode ser medido e calculado. Criada pelos engenheiros norte-americanos Claude Shannon e Warren Weaver em 1949, essa teoria propôs analisar a eficácia da transferência de informação apenas sob um ponto de vista sintático, não considerando os fatores semânticos e pragmáticos associados a ela. Dessa forma, o tipo de informação estudado foi a informação objetiva, a qual poderia ser processada em sistemas para a recuperação de informações (CAPURRO, 2003; WERSIG, 1996; ARAÚJO, 2011; ALMEIDA, 2015).

A partir dessa perspectiva, a informação também pode ser compreendida como um dado ou como uma coisa. Buckland (1991) defende que todos os registros e objetos são potencialmente informativos e que a informação como coisa merece ser estudada na CI por ser a única forma de informação que é diretamente tratada pelos sistemas de informação. Argumenta ainda que as pessoas são informadas não apenas por meio de comunicados convencionais, mas também a partir de uma extensa variedade de objetos e eventos.

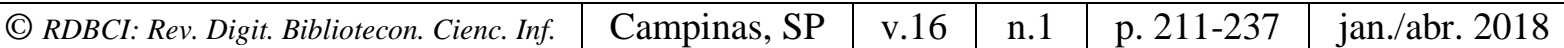


No entanto, para que ocorra o processamento desta informação, é necessária a mobilização de estruturas que denotem significados a ela. A interpretação da informação e a atribuição de valor a um documento são elementos que caracterizam a vertente cognitiva da informação, que procura ver como o usuário atribui sentido à informação e como ele é transformado durante o processo informacional (CAPURRO, 2003), ou seja, como aquela informação alterou o seu estado de conhecimento (BARRETO, 2002).

Contudo, ao invés dessa interpretação ser considerada apenas num plano subjetivo individual, para alguns autores ela é determinada no contexto social e cultural (CAPURRO; HJØRLAND, 2007). A faceta social da informação, portanto, vai além da cognição ou da individualidade do sujeito, considerando os condicionamentos sociais e materiais da existência humana (CAPURRO, 2003).

Assim, o que define o processo informacional são as próprias definições do que cada sujeito cognoscente social considera como informação, do que ele seleciona e coloca como critério para acessar ou descartar, num processo sócio-histórico (CAPURRO, 2003). Produzir, acessar ou compartilhar informações "pressupõe em seu ato, o reconhecimento direto por parte do indivíduo de que é ele o principal protagonista desse processo complexo que envolve tanto entidades humanas como não-humanas" (SILVA; NUNES, 2014, p. 253).

A informação revela-se, portanto, como o resultado da interpretação que o indivíduo faz da sua realidade. A construção do conhecimento se dá em um plano individual, grupal e social de forma dialética entre a objetividade da realidade e a significação subjetiva que lhe é atribuída pelos sujeitos (BERGER; LUCKMANN, 2014).

Desse modo, concordamos com Almeida Júnior (2007) quando afirma que a informação não existe a priori, mas apenas se concretiza no momento da mediação. O que existe antecipadamente é o documento ou o suporte, mas a apropriação da informação se dá quando o sujeito mediante leitura em sentido amplo (decodificação e decifração da mensagem até compreensão inferente) constrói a informação. A informação aqui é considerada uma fonte "abaladora" de geração de conflitos que, ao invés de diminuir as certezas, suscita novas perguntas, e assim proporciona a construção de novos conhecimentos (ALMEIDA JÚNIOR, 2009).

Por mediação da informação, compreende-se o processo que vai desde a comunicação via suporte até a transformação do conhecimento do sujeito. O que não se refere apenas ao sujeito estritamente em sua estrutura individual, mas tendo como dependente e co-construtor também o coletivo (aspectos históricos, sociais, interação com outros sujeitos) (ALMEIDA JÚNIOR, 2009; 2007).

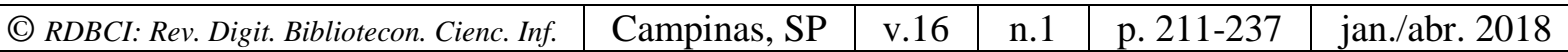


A apropriação informacional, por sua vez, não se refere apenas a uma ação de consumo ou recepção da informação, mas remete à ideia de alteração, mudança e produção de conhecimento (ALMEIDA JÚNIOR, 2007). Nos ambientes informacionais, continua o autor:

\begin{abstract}
A mediação está presente, de maneira não explicitada, na seleção, na escolha dos materiais que farão parte do acervo da biblioteca, em todo o trabalho de processamento técnico, nas atividades de desenvolvimento de coleções e, também, no serviço de referência e informação. Presente em todas essas ações, a mediação faz parte do próprio objeto da área de informação. Especificamente, em relação à área de Ciência da Informação, o seu objeto passaria a ser mais a mediação do que a informação (ALMEIDA JÚNIOR; BORTOLIN, 2008, p. 6-7).
\end{abstract}

É, portanto, a partir deste contexto que considera que a concretização da informação se dá por meio de um processo mediacional mediante leitura e este, por sua vez, resulta no processo de apropriação informação que se constrói de forma individual e coletiva que passamos a compreender o conceito de prática informacional.

Conforme Savolainen (2007), o comportamento informacional e as práticas informacionais são, de maneira geral, formas pelas quais as pessoas lidam com informações. Entretanto, não são termos sinônimos, mas carregados de sentidos distintos, originados por concepções teóricas e discursos diferentes.

Os argumentos de Savolainen (2007) afirmam que o conceito de práticas informacionais é mais orientado social e contextualmente do que o conceito de comportamento informacional. A ideia de prática informacional desloca a ênfase das habilidades e motivações dos indivíduos isoladamente para a busca e o uso da informação construída dialogicamente em meio às interações sociais. Para o autor o conceito, liga-se aos fatores contextuais de busca e compartilhamento de informações, colocando os fatores sociais e culturais no plano central de análise.

Desse modo, o autor citado expande a pesquisa de informação ampliando o foco para além da busca, abrangendo o uso e compartilhamento de informações e transcendendo para ambientes fora do local de trabalho, fora das organizações, na preocupação com a busca e o uso da informação na vida cotidiana de modo contextual (SAVOLAINEN, 2008).

As práticas informacionais podem ser entendidas, portanto, como "conjunto de maneiras social e culturalmente estabelecidas para identificar, buscar, usar e compartilhar as informações disponíveis em várias fontes, tais como televisão, jornais e Internet" (SAVOLAINEN, 2008). Tal conceito também compreende as ações de mediação da informação e apropriação da informação, as quais pressupõem um movimento de partilha por meio da leitura que promove a interação e a negociação entre sujeitos, de forma que eles se apropriem de informação e produzam conhecimento.

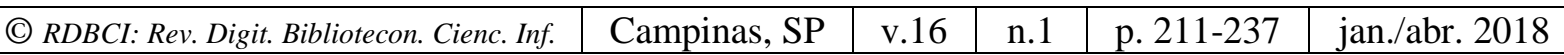


A abordagem sobre as práticas informacionais é importante, destarte, por considerar o sujeito um ator social que, além se ser um ser ativo na busca e compartilhamento de suas ações, realiza suas ações em meio a uma coletividade e atribui significado a elas.

Ao protagonizar essas ações, os sujeitos demostram competências em informação no ato da busca, uso, apropriação, produção e compartilhamento dessas informações, incluindose nisto a capacidade de fazer relações, discernir, inferir e usar a informação de forma adequada, além de entender como informação não apenas aquela ligada ao conhecimento científico, mas também ao saber do povo, ao senso comum e ao mundo empírico (ALMEIDA JÚNIOR, 2016).

Nesse sentido, para além do uso da informação, a concepção de negociação e compartilhamento da informação torna o processo de mediação uma ação conjunta de diálogo, interação e discussão que promove e estimula as práticas informacionais dos sujeitos. A interação pressupõe participação efetiva dos sujeitos e ação transformadora, oportunizada pelo diálogo.

Assim, como forma de reflexão sobre esses conceitos compreendemos que as práticas informacionais e leitoras são conceitos tratados de forma ampla. Eles implicam as ações de busca, produção, apropriação e compartilhamento de informações, as quais são adquiridas mediante o uso da leitura por um processo mediado por diversos interferentes contextuais, humanos, culturais e tecnológicos. Os conhecimentos, habilidades, sentimentos, valores e vivências adquiridos e transformados durante esses processos também compreendem as práticas informacionais e leitoras.

Consideramos diante da discussão teórica proposta que a apropriação da informação é um processo que envolve instâncias coletivas que de forma mediada provocam decisões/sensações individuais acerca dos modos de ler e se informar. Tanto na explanação sobre práticas leitoras como na exposição referente às práticas informacionais, o conceito de contexto é posto em evidência visto que as ações individuais dos sujeitos estão estritamente envencilhadas com suas ações históricas, sociais e grupais.

\section{BIBLIOTECAS COMUNITÁRIAS}

Ao iniciar uma discussão conceitual do termo "bibliotecas comunitárias", Almeida Júnior (1993) considerou que a biblioteca comunitária seria uma modalidade do conceito de biblioteca alternativa. Esta última é definida por ele como sendo todas as propostas que viessem mudar ou alterar os trabalhos da biblioteca tradicional, a exemplo dos conceitos de "Biblioteca-Ação Cultural", "Biblioteca-Centro Cultural" do Flusser, "Centro de Documentação Popular", Serviço Referencial e de Informação, bem como bibliotecas populares e comunitárias.

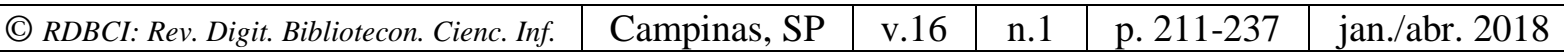


Posteriormente, em complemento à concepção de Almeida Junior (1993), Machado (2008) aponta cinco elementos peculiares às bibliotecas comunitárias que as distinguem dos outros tipos de biblioteca. São eles:

1. a forma de constituição: são bibliotecas criadas efetivamente pela e não para a comunidade, como resultado de uma ação cultural.

2. a perspectiva comum do grupo em torno do combate à exclusão informacional como forma de luta pela igualdade e justiça social. 3. o processo de articulação local e o forte vínculo com a comunidade. 4. a referência espacial: estão, em geral, localizadas em regiões periféricas. 5. o fato de não serem instituições governamentais, ou com vinculação direta aos Municípios, Estados ou Federação (MACHADO, 2008, p. 60-61, grifos do autor).

Ressaltamos que, de fato, as bibliotecas comunitárias não deixam de ter o caráter alternativo à biblioteca pública como destacado por Almeida Junior. Mas também concordamos com Machado quando pontua os outros elementos, pois eles representam de maneira concreta a forma de constituição das bibliotecas comunitárias, sobretudo aquelas que fazem parte do nosso lócus de pesquisa, a Releitura.

As bibliotecas comunitárias se apresentam como um novo tipo de biblioteca que, apesar de também serem espaços públicos de informação, são mantidas por pessoas da sociedade em geral (FERNANDEZ; MACHADO, 2016). Constituem espaços que buscam ser um local de acesso à informação, leitura e cultura de pessoas que, muitas vezes, não possuem outros espaços de educação, cultura e lazer.

A Releitura, Bibliotecas Comunitárias em Rede da Região Metropolitana do Recife, é uma articulação que surgiu em 2007, incialmente com quatro bibliotecas comunitárias. Posteriormente, mais quatro bibliotecas se reuniram com o grupo para se fortalecerem enquanto coletivo, com troca de informações, ajuda mútua e aprimoramento na formação (RELEITURA, 2013).

Até 2013, a Releitura era composta por dez bibliotecas integrantes. Hoje, conta com sete bibliotecas. O coletivo tem como missão fortalecer e qualificar as bibliotecas comunitárias da Região Metropolitana do Recife visando à formação de comunidades leitoras na perspectiva de construção de um projeto de sociedade mais justa, plural e democrática (RELEITURA, 2014).

As bibliotecas que fazem parte da Releitura atuam nos municípios de Jaboatão dos Guararapes, Olinda e Recife, atendendo a cerca de 15 mil pessoas entre crianças e jovens e suas famílias. O coletivo busca fortalecer e democratizar o acesso ao livro e à cultura escrita nessas comunidades por meio de diversas ações em cada biblioteca. Além de buscar fomentar

\begin{tabular}{|c|c|c|c|c|}
\hline (C) RDBCI: Rev. Digit. Bibliotecon. Cienc. Inf. & Campinas, SP & v.16 & n.1 & \\
\hline
\end{tabular}


o quadro político-pedagógico das bibliotecas comunitárias e lutar pela construção de políticas públicas em prol da leitura e biblioteca (RELEITURA, 2013, 2014).

Desde o início, a Releitura conta com a parceria do Centro de Cultura Luiz Freire, em 2007, e do Instituto C\&A (IC\&A), em 2008, por meio do Programa Prazer em Ler. Participa e atua junto ao Fórum Pernambucano em Defesa das Bibliotecas, Livro, Leitura e Literatura (FDBLLL/PE) para a criação dos Planos Estaduais e Municipais do Livro e da Leitura. Em 2012, tornou-se parceira do Centro de Estudos em Educação e Linguagem (CEEL) da UFPE, que promoveu, em 2014, uma série de ações, entre as quais o subprojeto do Programa Nacional de Alfabetização na Idade Certa (PNAIC) (RELEITURA, 2014).

A inciativa do grupo Releitura na RMR enquanto uma rede de bibliotecas comunitárias é pioneira no Brasil, influenciando a formação de outras redes de bibliotecas no país. Atualmente, ela integra também a Rede Nacional de Bibliotecas Comunitárias (RNBC), um coletivo formado por várias redes estaduais e regionais desse tipo de bibliotecas (RELEITURA, 2013).

\section{DESENHO METODOLÓGICO}

Nosso processo metodológico, além da pesquisa bibliográfica de cunho exploratório, contemplou um estudo empírico de cotejo de informações sobre as bibliotecas comunitárias e a coleta de depoimentos com sujeitos que fazem parte dessas bibliotecas por meio de entrevistas semiestruturadas, as quais foram analisadas e categorizadas por meio da técnica de Análise de Conteúdo (BRADIN, 2008)

As quatro bibliotecas que formaram o corpo empírico da pesquisa foram em ordem alfabética: Biblioteca Comunitária Amigos da Leitura (BAL), criada em 2004 por um morador do bairro junto com algumas instituições parceiras; a Biblioteca do CEPOMA (BCEPOMA), criada em 2006 dentro de um centro de educação popular fundado pela comunidade; Biblioteca Multicultural do Nascedouro (BMN), criada em 2000 por jovens da comunidade junto com instituições parceiras e Biblioteca Popular do Coque (BPC), criada em 2006 por uma moradora da comunidade junto com instituições parceiras. Até hoje, todas essas bibliotecas são mantidas pelos membros da comunidade, idealizadores e parceiros.

As entrevistas foram feitas com gestores, mediadores e interagentes das quatro bibliotecas comunitárias. A coleta dos depoimentos ocorreu do dia 30 de setembro ao dia 07 de dezembro de 2016, incluindo o pré-teste. Ao todo, foram 31 entrevistas, perfazendo um total de quase 40 horas (sendo o menor tempo de entrevista 29 minutos e o maior tempo de entrevista 6 horas) e 305 páginas de transcrição, além das horas passadas antes e depois das entrevistas em cada biblioteca ou local da entrevista.

\begin{tabular}{l|l|l|l|l|l}
\hline (C) RDBCI: Rev. Digit. Bibliotecon. Cienc. Inf. & Campinas, SP & v.16 & n.1 & p. 211-237 & jan./abr. 2018 \\
\hline
\end{tabular}


Para a análise das entrevistas formais, usamos a técnica da análise de conteúdo definida e estrutura por Laurence Bardin (2008), que define essa forma de análise de dados como um conjunto de técnicas de análise das comunicações (discursos orais ou textos escritos) que usa procedimentos sistemáticos e objetivos de descrição do conteúdo das mensagens. A análise de conteúdo foi escolhida porque considera mais as significações (o conteúdo) do que a forma (a análise de ocorrência).

Optamos por realizar uma análise categorial, que constitui uma operação de classificação seguida de reagrupamento segundo o gênero de acordo com critérios definidos anteriormente. Opera por meio do desmembramento do texto em unidades (categorias) conforme análise temática proposta (BARDIN, 2008). Neste estudo, os temas em questão foram delineados em função das duas questões básicas da pesquisa: as práticas informacionais e as práticas leitoras dos sujeitos envolvidos com as bibliotecas comunitárias. Todavia, reforça-se que as categorias aqui utilizadas não buscam apenas incluir os elementos comuns de cada grupo, mas sim apresentar seus conflitos, singularidades, diferentes posicionamentos sobre um fato e multiplicidade de visões, práticas e afinidades.

\section{DESCOBRINDO OS ATORES E SUAS PRÁtICAS}

Então, a leitura amplia nosso campo de visão, nosso raio de visão e ampliando seu campo de visão você tem uma perspectiva de futuro, porque quando a pessoa está só ali na sua "caixinha", ela acha que a vida é aquilo, ela não transcende aquilo (Sérgio, gestor).

Em se tratando do perfil dos entrevistados, temos pessoas de diferentes formações e ocupações que possuem envolvimento extenso com as bibliotecas. Todos eles residem na RMR, estando a maioria localizada em Recife (19) e Olinda (11). A formação e ocupação dos 18 sujeitos gestores e mediadores das bibliotecas é heterogênea, contemplando em sua maioria áreas ligadas à Educação. Os níveis escolares vão desde o ensino médio (1), graduação (10), magistério (1), especialização (2) ao mestrado (4). Cerca de cinco deles possuem envolvimento de 10 a 30 anos com as bibliotecas e 11 possuem ligação de até 10 anos com a biblioteca.

Sobre os interagentes das bibliotecas, a faixa etária variou de 11 a 34 anos, com níveis de escolaridade do $2^{\circ}$ ano do Ensino Fundamental até o nível técnico. A maior parte é estudante, contendo também um artista de rua e uma doméstica. Moram com duas até sete pessoas em casa. Sete deles apontaram a frequência de familiares, como mães, irmãos e sobrinhos, à biblioteca.

Devido a razões de cunho ético as bibliotecas serão tratadas por suas siglas e os nomes dos entrevistados foram trocados para manter sua integridade, preservando apenas o sexo. Escolheu-se para essa substituição nomes de personagens literários. Ressaltamos que os

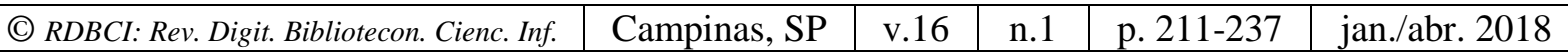


resultados apresentados mostram alguns dos elementos analisados na pesquisa original, por isso a inclusão de quadros de forma a sintetizar e ilustrar melhor o conteúdo de cada categoria.

\subsection{A LEITURA COMO FIO: práticas leitoras e informacionais dos sujeitos}

Ler é outra história, ler é tudo de bom, sabe como é, né, é o máximo do máximo, ouvir a história é bom, mas ler com seus próprios olhos é mágico (Ana Clara, educadora)

Por entendermos que a leitura é a instância que une e que reuniu todas essas pessoas, sentimentos e vontades em torno dessa rede de bibliotecas, mesmo sabendo que para alguns a relação com a leitura já existia antes da biblioteca e em outros essa relação só veio surgir a partir dela, optamos por categorizar como primeira instância de análise a leitura como o fio que impulsionou e estabeleceu o vínculo entre essas pessoas e as estimulou a ler mais, informar-se e estar na biblioteca.

Notou-se que os sujeitos possuem uma relação ampla com a leitura, mesmo que majoritariamente tenham citado o livro como o principal suporte. Alguns entrevistados observaram o conceito amplo de leitura de mundo, tanto realizado por eles como passado e trabalhado com os interagentes. Mesmo considerando como base principal a palavra escrita, a leitura representa para os depoentes uma variedade de valores e prazeres, uma fonte de conhecimento e sabedoria, bem como uma porta para o mundo da ficção e da criação. Nesse sentido, o entrevistado Leonardo diz:

Eu sou meio dramático com isso, sabe? Porque leitura é como beber água. Se você deixa de beber água, você vai ficar com sede, vai morrer, desidratar. Então, se você deixar de ler, eu acho que você se torna uma pessoa menos criativa, mais apática com o mundo, mais apática com você mesmo. Eu tenho a necessidade de ser desestabilizado a todo o momento. Para mim, eu busco na leitura essa desestabilização e esse crescimento, tanto pragmático, em termo de vocabulário, em termo de raciocínio lógico, e tem uma dimensão subjetiva da sensibilidade, da tua relação com o mundo, do teu carinho com as coisas, dessa coisa de se apaixonar fácil. Eu acho que a leitura é uma grande fonte de força.

Para tratar da busca, uso e partilha de informação pelos depoentes, percebemos a leitura de textos escritos como fator impulsionador e influente desse processo, porquanto foi a forma mais citada para se obter informações. Constatou-se, portanto, a posição de Almeida Júnior (2009), ao afirmar que só existe apropriação da informação mediante a realização da leitura, embora este considere leitura em seu sentido amplo, e não apenas a leitura de textos escritos.

Observa-se nas práticas informacionais dos entrevistados, o uso da competência em informação e leitora, que permite, por meio das habilidades adquiridas, a apropriação da

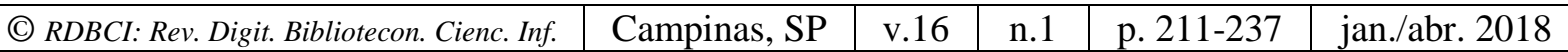


informação. E isso reflete tanto a forma que se conduzem os espaços informacionais, nos quais atua a figura interferente do mediador, como na interação gerada pelos leitores, que se mesclam e se amalgamam nas trocas e compartilhamentos de informações. De maneira sintética, montamos um quadro que resume os principais elementos que representam as práticas leitoras e informacionais dos sujeitos da pesquisa.

Quadro 1 - Práticas leitoras e informacionais

\begin{tabular}{|c|c|c|}
\hline & PRATICAS LEITORAS & PRÁTICAS INFORMACIONAIS \\
\hline $\begin{array}{c}\text { Gestores } \\
\text { (bibliotecas e } \\
\text { Releitura) }\end{array}$ & \multirow{2}{*}{$\begin{array}{l}\text { Contato com a leitura inicia na fase juvenil e } \\
\text { adulta. Influência da oralidade. O gostar de ler } \\
\text { surge com contato de bibliotecas públicas, } \\
\text { escolares e com a biblioteca comunitária. } \\
\text { Preferências por gêneros literários como } \\
\text { romances, biografias, poesias. Uso restrito a } \\
\text { outras unidades de informação, sendo o } \\
\text { contato maior com a biblioteca comunitária. } \\
\text { Aquisição de livros é feita por meio do acesso } \\
\text { à biblioteca comunitária, compra ou ganho. A } \\
\text { leitura é tida como vital, fonte de saber, } \\
\text { humanização e politização. }\end{array}$} & \multirow{3}{*}{$\begin{array}{l}\text { Maneiras de se informar vão desde livros, bases } \\
\text { de dados, portais de notícias, redes sociais na } \\
\text { Internet e colegas. Predominância do uso da } \\
\text { leitura de fontes escritas impressas ou digitais. } \\
\text { Amplo uso da Internet por meio de mecanismos } \\
\text { de buscas e redes sociais e por meio destas, } \\
\text { utilização de outras modalidades de leitura } \\
\text { como imagens, sons e vídeos. Uso de canais } \\
\text { informativos alternativos em função do caráter } \\
\text { manipulador e tendencioso dos grandes veículos } \\
\text { de comunicação, buscando dessa maneira fontes } \\
\text { que respondam aos seus anseios tendo em vista } \\
\text { seus contextos históricos e sociais de luta e } \\
\text { engajamento politico. }\end{array}$} \\
\hline $\begin{array}{c}\text { Mediadores } \\
\text { (mediadores de } \\
\text { leitura e } \\
\text { educadoras) }\end{array}$ & & \\
\hline Interagentes & $\begin{array}{l}\text { Contato com a leitura se inicia na infância. } \\
\text { Presença maior do texto escrito. O gostar ou } \\
\text { aprender a ler surge com o contato com a } \\
\text { biblioteca comunitária. Preferências por } \\
\text { gêneros literários em séries e publicações } \\
\text { recém-lançadas ou best-sellers. Uso restrito a } \\
\text { outras unidades de informação, sendo o } \\
\text { contato maior com a biblioteca comunitária. } \\
\text { Aquisição de livros é feita por meio do acesso } \\
\text { à biblioteca comunitária. A leitura é tida como } \\
\text { fonte de conhecimento, meio para } \\
\text { aprimoramento da fala e da escrita, forma de } \\
\text { viajar na imaginação, humanização, } \\
\text { tranquilidade e construção de si mesmo. }\end{array}$ & \\
\hline
\end{tabular}

Fonte: Dados da pesquisa

\subsection{A BIBLIOTECA COMO ARTESÃ: costurando as práticas leitoras e informacionais}

Considerando que foram as práticas leitoras e informacionais desses sujeitos que os impulsionaram a forjar os espaços de leitura, destacaremos nesta seção as práticas resultantes da criação de cada biblioteca e da conexão das bibliotecas (a Releitura) e suas parcerias, conforme Figura 1. 


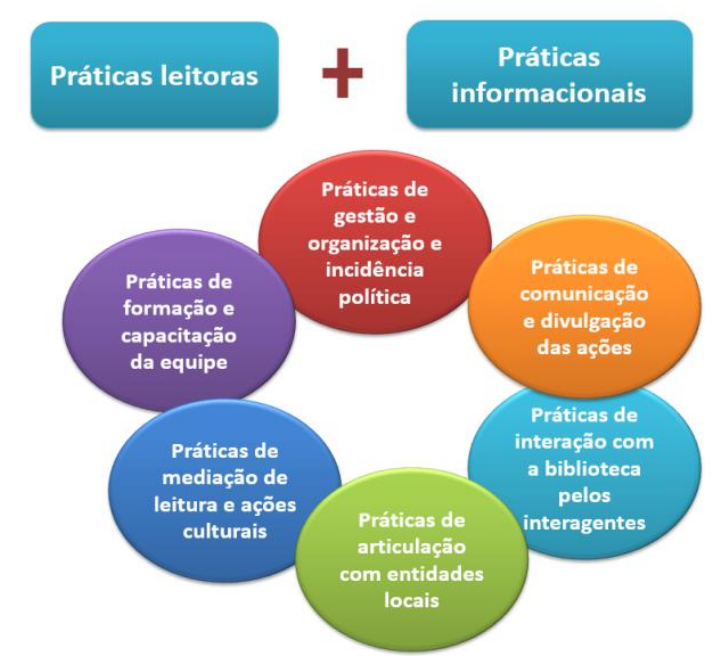

Figura 1 - Esquema representativo dos desdobramentos das práticas leitoras e informacionais

Fonte: Elaboração própria (2017)

\subsubsection{Práticas de gestão e organização e incidência política}

Uma das preocupações que as bibliotecas sempre demonstraram ter e sempre se esforçaram para buscar novas alternativas para melhoria foi com relação à maneira de gerir seus espaços, seja enquanto bibliotecas individuais ou enquanto Releitura. No início, cada biblioteca tentava fazer os serviços da melhor da maneira possível, mas elas não tinham uma prática de gestão estruturada. Ao passo que elas foram adquirindo conhecimento da existência de outras bibliotecas comunitárias e foram se articulando, passaram a trocar informações sobre como cada uma atuava, chegando, assim, a se organizar em Rede e a manter muitos procedimentos em comum, conforme Quadro 2.

Quadro 2 - Práticas de gestão e organização e incidência política

\begin{tabular}{|c|c|}
\hline & PRÁTICAS DE GESTÃO E ORGANIZAÇÃO E INCIDÊNCIA POLÍTICA \\
\hline $\begin{array}{c}\text { Gestores } \\
\text { (bibliotecas e } \\
\text { Releitura) }\end{array}$ & $\begin{array}{l}\text { Criação da Releitura. Realização de práticas conjuntas e organização de procedimentos em } \\
\text { comum. Criação de uma gestão compartilhada por meio do desenvolvimento de Grupos de } \\
\text { Trabalhos. Parceria com CCLF para desenvolvimento político e educacional das } \\
\text { bibliotecas. Parceria com Programa Prazer em Ler (Instituto C\&A) que fornece apoio } \\
\text { pedagógico, financeiro e incentivo à participação e formulação das políticas públicas para } \\
\text { o setor do livro, leitura, literatura e biblioteca. Incidência por meio do FDBLLL/PE na } \\
\text { elaboração e monitoramento das políticas públicas do Estado para causa do livro e } \\
\text { biblioteca. }\end{array}$ \\
\hline $\begin{array}{c}\text { Mediadores } \\
\text { (mediadores de } \\
\text { leitura e } \\
\text { educadoras) }\end{array}$ & $\begin{array}{l}\text { Por se tratar de uma gestão compartilhada tanto os mediadores como os gestores } \\
\text { participam das decisões e atuam de forma conjunta na articulação e execução das ações. }\end{array}$ \\
\hline Interagentes & $\begin{array}{l}\text { Os interagentes são o foco principal de todas as ações de gestão que as bibliotecas } \\
\text { realizam, embora não participem diretamente, é em função de otimizar cada vez mais os } \\
\text { serviços e os espaços e proporcionar um melhor ambiente para eles que os gestores e } \\
\text { mediadores mobilizam esses esforços. }\end{array}$ \\
\hline
\end{tabular}

Fonte: Dados da pesquisa 


\subsubsection{Práticas de formação e capacitação da equipe}

A busca e o desejo de capacitação surgem em meio a um contexto de atuação empírica em que as bibliotecas foram criadas, cuja iniciativa parte de pessoas não ligadas ao campo da Biblioteconomia, mas que tinham vínculos com o campo da Educação e viam no livro a possibilidade de mudança de vida da comunidade. Por isso, embora não tivessem o conhecimento teórico incialmente, aos poucos elas o foram buscando como forma de aprimoramento da sua atuação prática, conforme Quadro 3.

Quadro 3 - Práticas de formação e capacitação da equipe

\begin{tabular}{|c|c|}
\hline & PRÁTICAS DE FORMAÇÃO E CAPACITAÇÃO DA EQUIPE \\
\hline $\begin{array}{l}\text { Gestores } \\
\text { (bibliotecas e } \\
\text { Releitura) }\end{array}$ & $\begin{array}{l}\text { O agenciamento de parcerias para capacitar a equipe surge para aprimorar as habilidades } \\
\text { que estes sujeitos já possuem e como forma de harmonizar a prática com a teoria. O CCLF } \\
\text { incialmente com capacitações sobre como montar espaços de leitura e qualificação de } \\
\text { escolas comunitárias de educação infantil e posteriormente com oficinas de leitura, } \\
\text { elaboração de projetos, formação política e social. O Programa Prazer em Ler oferece } \\
\text { formação continuada aos profissionais das bibliotecas bem como promove encontros, } \\
\text { seminários regionais e nacionais e grupos de estudos para interação, troca e criação de } \\
\text { informações referente às bibliotecas comunitárias. O CEEL inicialmente ofereceu uma } \\
\text { formação teórica envolvendo temas como formação de leitor e leitura literária, que ao se } \\
\text { mesclar com a atuação prática das bibliotecas foi se fortalecendo e hoje ambos mantêm } \\
\text { uma relação de troca e as equipes das bibliotecas também atuam como formadoras em } \\
\text { projetos do CEEL. Ressalta-se o empenho e dedicação da Releitura tanto na articulação } \\
\text { como na execução dessas ações. }\end{array}$ \\
\hline $\begin{array}{l}\text { Mediadores } \\
\text { (mediadores de } \\
\text { leitura e } \\
\text { educadoras) }\end{array}$ & $\begin{array}{l}\text { Essas capacitações, encontros e trocas possibilitam aos mediadores e a todos os envolvidos } \\
\text { o aprimoramento de suas atividades e de sua atuação na biblioteca e na comunidade, bem } \\
\text { como em outros espaços de atuação e se refletem em suas próprias vidas. }\end{array}$ \\
\hline Inte & $\begin{array}{l}\text { E a partir das demandas apresentadas pelos interagentes que os gestores e mediadores } \\
\text { buscam formas de aperfeiçoamento das ações. }\end{array}$ \\
\hline
\end{tabular}

Fonte: Dados da pesquisa

\subsubsection{Práticas de comunicação e divulgação das ações}

Em todas as atividades e ações realizadas, a equipe da biblioteca sempre faz o possível para registrá-las e divulgá-las, desde a etapa do planejamento até o momento da execução. Por isso, outra prática informacional e leitora observada foi a produção e compartilhamento da informação realizada por meio dos dispositivos de divulgação das atividades, seja em cartazes, redes sociais ou oralmente.

A comunicação representa além de uma prática que mantêm as ações registradas, uma forma de prestação de contas à sociedade das ações que se realizam nesses espaços. Constituem-se ações informacionais inseparáveis do contexto social, histórico, cultural e político no qual estas práticas estão inseridas, configurando-se como um movimento mediador de recepção, apropriação e reapropriação da informação. A síntese desta categoria é apresentada no Quadro 4. 
Quadro 4 - Práticas de comunicação e divulgação das ações

\begin{tabular}{|c|c|}
\hline & PRÁTICAS DE COMUNICAÇÃO E DIVULGAÇÃO DAS AÇÕES \\
\hline $\begin{array}{l}\text { Gestores } \\
\text { (bibliotecas e } \\
\text { Releitura) }\end{array}$ & $\begin{array}{l}\text { A comunicação ocorre de forma interna (comunidade) e externa (público fora da } \\
\text { comunidade). Formas de divulgação impressa (oral, audiovisual e imagética) e em redes } \\
\text { sociais na internet, se destacando os seguintes meios: blog, Facebook, comunicação oral e } \\
\text { cartazes. A comunicação em algumas unidades de mostrou deficiente, seja por falta de } \\
\text { recursos ou seja pela ausência de pessoal para realizar essas ações. As estratégias e ações }\end{array}$ \\
\hline $\begin{array}{l}\text { Mediadores } \\
\text { (mediadores de } \\
\text { leitura e } \\
\text { educadoras) }\end{array}$ & $\begin{array}{l}\text { de comunicação e divulgação das atividades demostram que além da criação de } \\
\text { informações as bibliotecas se preocupam em registrar e divulgar seus feitos revelando um } \\
\text { ciclo de apropriação, registro e disseminação de informações. }\end{array}$ \\
\hline Interagentes & $\begin{array}{l}\text { Os interagentes se apresentam tanto como receptores como divulgadores de informações, } \\
\text { quando também informam e compartilham com seus colegas e familiares sobre as } \\
\text { atividades ocorridas ou que irão ocorrer nas bibliotecas seja de modo presencial ou virtual } \\
\text { por meio das redes sociais na internet. }\end{array}$ \\
\hline
\end{tabular}

Fonte: Dados da pesquisa.

\subsubsection{Práticas de mediação de leitura e ações culturais}

Outra prática de leitura e informação entendida para nós como o momento em que as bibliotecas fazem uso da mediação e apropriação da informação e leitura são as atividades e serviços oferecidos por elas, que serão vistos tanto do ponto de vista da equipe como da interação pelos interagentes.

A Mediação de leitura é a atividade mais desenvolvida em todas as bibliotecas, porque envolve diversos tipos de ações que têm como fim a interação e o contato entre a obra e o leitor. Também é considerada pela Releitura uma ação capaz de promover o gosto pela leitura e pela cultura letrada nas comunidades onde as bibliotecas comunitárias estão inseridas. Inclui diversas atividades, como rodas de leitura, recitais, bate-papo com autor, visitas a espaços culturais, contação de histórias, entre outras atividades.

Outras atividades realizadas nas bibliotecas que promovem o encontro com a cultura acontecem por meio de uma multiplicidade de suportes ou expressões, seja através da palavra escrita ou oral, como lendas, contos, parlendas, músicas ou por meio da imagem, do teatro, da dança, da percussão, do cinema, bem como a expressão em si, como outras expressões como a capoeira, o maracatu, o bumba-meu-boi.

Destarte, temos que o trabalho desenvolvido nessas bibliotecas está pautado numa linha de pensamento que tem como função primordial o desenvolvimento de habilidades de leitura e criação, a partir de uma proposta integradora e de um ambiente receptivo e adaptado ao uso de qualquer tipo de público. Todo o cuidado, planejamento, estudo e oferecimento de ações empreendidas pelos gestores e mediadores são feitos com o fim de inclusão, de aproximação do leitor com a obra, de modo a propiciar vivências diversas e superação de desafios. A intenção é oferecer um ambiente agradável de leitura, de lazer ou de refúgio, já

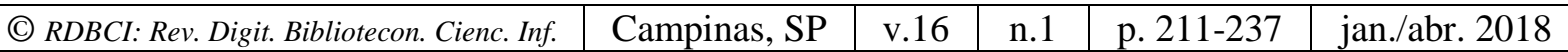


que muitas vezes a biblioteca é o único equipamento cultural existente na comunidade. $\mathrm{O}$ Quadro 5 sintetiza algumas considerações sobre essas práticas.

Quadro 5 - Práticas de mediação de leitura e ações culturais

\begin{tabular}{|cl|} 
Ps atividades de mediação de leitura e ações culturais se revelam por meio de diversas \\
$\begin{array}{c}\text { Gestores } \\
\text { manifestações como práticas de mediação e apropriação da leitura e da informação. }\end{array}$ \\
$\begin{array}{l}\text { Envolvem todo um processo de planejamento e organização para a criação das atividades. } \\
\text { Releitura) }\end{array}$ & $\begin{array}{l}\text { Incluem ações com leitura, escrita, cultura, arte e brincadeira. Promovem o } \\
\text { desenvolvimento de habilidades leitoras e escritas, bem como proporcionam o fomento de } \\
\text { valores. }\end{array}$ \\
\hline $\begin{array}{c}\text { Mediadores } \\
\text { (mediadores de } \\
\text { leitura e }\end{array}$ & $\begin{array}{l}\text { O mediador de leitura é o principal condutor dessas ações que procura desenvolver } \\
\text { atividades adequadas para cada tipo de público e busca potencializar a inventividade de } \\
\text { cada interagente. Também é visto como uma pessoa de referência por estes últimos. }\end{array}$ \\
\hline $\begin{array}{l}\text { Interagentes } \\
\text { Usufruem de forma interativa e avaliativa das ações de mediação de leitura e atividades } \\
\text { culturais. }\end{array}$
\end{tabular}

Fonte: Dados da pesquisa

\subsubsection{Práticas de articulação com entidades locais}

Optamos para esta categoria, considerar como entidades locais instituições de ensino ou organizações de base comunitárias com as quais as bibliotecas se relacionam. Contudo, as bibliotecas interagem com diversos tipos de instituições governamentais, não governamentais e comerciais dos bairros. A intenção foi pôr em relevo as atividades mútuas realizadas entre as bibliotecas e essas instituições de formação, por serem ações de troca destacadas por eles como fundamentais para ambas as atuações.

A interação das bibliotecas com as escolas é uma prática que ocorre como uma forma de fortalecer os laços de relacionamento com as crianças e estudantes da comunidade, seja para dar ou para ampliar o acesso à leitura, pois em muitas dessas escolas as bibliotecas não funcionam da forma como deveriam. Esta ação conjunta das bibliotecas com as escolas vem sendo calcificada por outra parceria, realizada entre a Releitura e o CEEL, que, por meio de formações e ações, vêm propiciando uma rotina de atividades de leitura para tal grupo.

Notamos que a busca de informações estimulada pelo trabalho com a leitura desenvolvido pela escola indica a formação do desenvolvimento da competência leitora desses alunos como atores que localizam, pesquisam, apropriam-se e disseminam informações já nesta fase inicial do período escolar. Por meio das atividades de mediação de leitura literária e das práticas semanais de leitura, esses estudantes foram adquirindo o gosto por ler e por se informar.

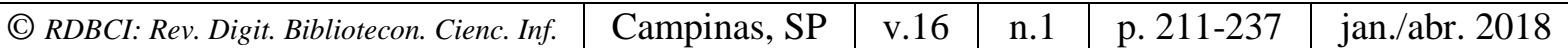


Para a professora da escola participante, Lúcia, a ação valeu muito a pena, sobretudo por ter despertado nas crianças o gosto pela leitura. Embora ela tenha notado que o interesse não foi de todos, a maioria das crianças se sentiu tocada pela leitura que, de uma maneira ou de outra, acabou contagiando a todos. Outro fato observado pela educadora neste grupo de crianças, que possui entre 11 a 13 anos, foi a troca de livros, os comentários sobre eles e a recomendação das leituras feitas. Assim, a educadora ressalta:

\begin{abstract}
Esse desejo por essa leitura de deleite, então isso foi muito interessante, a movimentação na biblioteca vindo pegar livros emprestados para ler, a movimentação que a gente gerou lá na [BMN], eles largando daqui e passando por lá para pegar livro para ler no final de semana. Então assim, entre todas as outras coisas, claro que ter escrito o livro, que ter desenhado, que ter feito a releitura toda foi muito importante, principalmente para eles se perceberem dessa forma, mas foi muito bom esse despertar.
\end{abstract}

Percebe-se que as práticas de parcerias com essas instituições formadoras são de ganhos mútuos entre elas e possuem boa recepção pelas crianças e jovens atendidos. $\mathrm{O}$ interesse pelo uso da biblioteca cresce, bem como o interesse pela leitura. Ressaltamos o trabalho desempenhado pelas educadoras mediadoras de leitura como de fundamental importância para o desenvolvimento do projeto, bem como a atuação da biblioteca na execução e articulação dessas parcerias. O Quadro 6 de maneira resumida mostra alguns pontos sobre essas práticas.

Quadro 6- Práticas de articulação com entidades locais

\begin{tabular}{|c|c|}
\hline & PRÁTICAS DE ARTICULAÇÃO COM ENTIDADES LOCAIS \\
\hline $\begin{array}{l}\text { Gestores } \\
\text { (bibliotecas e } \\
\text { Releitura) }\end{array}$ & $\begin{array}{l}\text { Realizada com escolas ou ONGs. Buscam promover a troca de ações entre as duas } \\
\text { instituições com o fim de fortalecer e ampliar o acesso à leitura dos estudantes e crianças } \\
\text { participantes. Ação potencializada a partir da parceria da Releitura com o CEEL. }\end{array}$ \\
\hline $\begin{array}{l}\text { Mediadores } \\
\text { (mediadores de } \\
\text { leitura e } \\
\text { educadoras) }\end{array}$ & $\begin{array}{l}\text { As educadoras e os mediadores de leitura planejam e põem em prática as ações de } \\
\text { letramento literário e atividades culturais por meio de atividades como leitura e releitura de } \\
\text { obras, rodas de leitura, trocas de livros, mala de leitura, oficinas, ações na escola e na } \\
\text { biblioteca comunitária. }\end{array}$ \\
\hline Interagentes & $\begin{array}{l}\text { Usufruem e interagem com as atividades adquirindo gosto pela leitura, habilidades de } \\
\text { leitura e de pesquisa, fluidez na leitura de textos e ampliação do mundo simbólico. }\end{array}$ \\
\hline
\end{tabular}

Fonte: Dados da pesquisa.

\title{
6.2.6 Práticas de interação com a biblioteca pelos interagentes
}

Notou-se que os modos com os quais os sujeitos se apropriam das bibliotecas estão sintonizados com a maneira em que o espaço foi criado e instalado e a forma como os frequentadores chegaram até ele. Assim, cada interagente conheceu a biblioteca de maneira muito condizente com a forma de criação desses espaços.

A aproximação que a equipe da biblioteca possui com os interagentes, devido a muitos membros serem da comunidade, é um fator que leva grande parte desses interagentes

\begin{tabular}{l|l|l|l|l|l} 
(C) RDBCI: Rev. Digit. Bibliotecon. Cienc. Inf. & Campinas, SP & v.16 & n.1 & p. 211-237 & jan./abr. 2018 \\
\hline
\end{tabular}


às bibliotecas. A relação de proximidade e acolhimento que o ambiente da biblioteca proporciona faz com que ela seja um espaço vivo e transformador. Os interagentes expressam admiração e gratidão à equipe das bibliotecas pelo cuidado, acolhimento e atenção dispensados a eles, não encontrados em outros espaços informacionais, o que constitui outro fator que garante a permanência deles nos espaços.

Essa configuração diferencial de atuação desenvolvida pelas bibliotecas comunitárias advém da concepção que elas têm do processo educativo e literário, que não condiz com uma metodologia tradicional de ensino e formação, mas sim com uma compreensão de que o processo formativo é constituído por uma estrutura de ações que demandam não apenas o arsenal de conhecimentos técnicos, mas também de concepções afetivas que ensejem vivências múltiplas. Acerca das formas de interação com a biblioteca, as ações de ler e pegar livros emprestados foram apontadas como as de mais interesse e uso pelos interagentes (Gráfico 1).

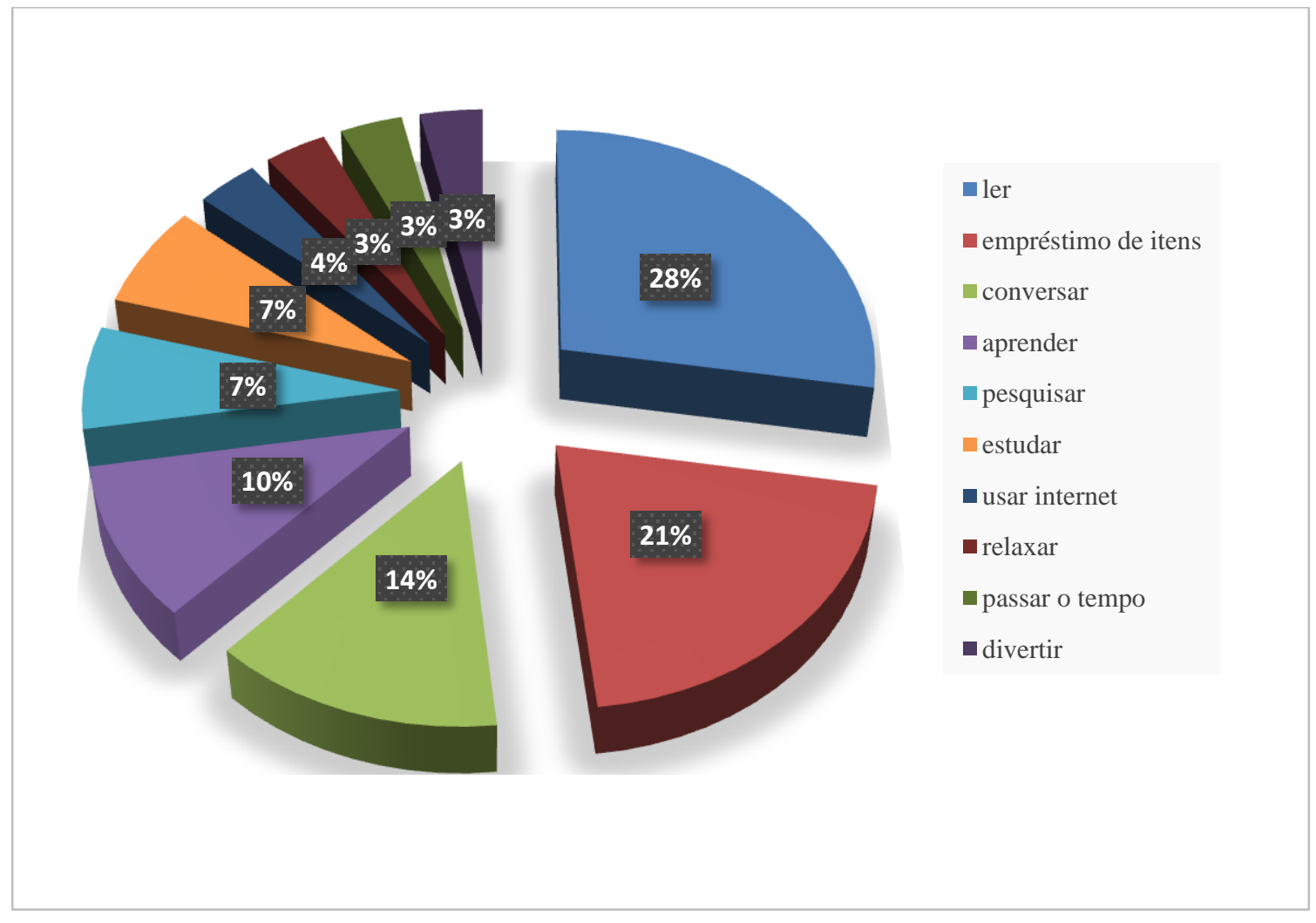

Gráfico 1- Motivos pelos quais os sujeitos interagem com a biblioteca.

Fonte: Dados da pesquisa

Compreendemos, portanto, que existe uma relação comunitária forte entre a população e as bibliotecas comunitárias, de modo que se percebe o quão imprescindível elas são para a comunidade e o quanto as pessoas precisam de um espaço que forneça

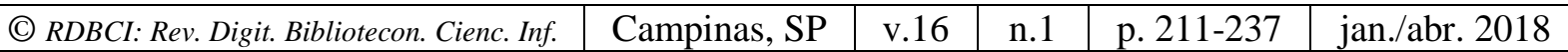


informações, livros, recreação e apoio e que esteja próximo a elas. A síntese dessa seção, se encontra no Quadro 7.

Quadro 7- Práticas de interação com a biblioteca pelos interagentes

\begin{tabular}{|cl|}
\hline $\begin{array}{c}\text { Gestores } \\
\text { (bibliotecas e } \\
\text { Releitura) }\end{array}$ & $\begin{array}{l}\text { PRATICAS biblioteca possui uma singularidade e essa peculiaridade está relacionada com a } \\
\text { forma como os interagentes chegam à biblioteca. }\end{array}$ \\
\hline $\begin{array}{c}\text { Mediadores } \\
\text { (mediadores de } \\
\text { leitura e } \\
\text { educadoras) }\end{array}$ & $\begin{array}{l}\text { A relação de proximidade e acolhimento que a equipe da biblioteca proporciona por meio } \\
\text { de suas atitudes e da ambiência é um fator que garante a permanência dos interagentes na } \\
\text { biblioteca e por ela se manter próxima a comunidade. }\end{array}$ \\
\hline O que atrai os interagentes a biblioteca é o acolhimento, atenção, qualidade do acervo e \\
mediadores. Interagem com a biblioteca, sobretudo, para ler, estudar, pegar livros \\
emprestados e conversar. A biblioteca é tida por eles como um local de leitura, convívio, \\
estudo e lazer. Gostariam que fossem oferecidos cursos de informática, mais atividades \\
culturais e que tivessem mais livros recém-lançados.
\end{tabular}

Fonte: Dados da pesquisa

\subsection{ALINHAVANDO REDES E PRODUZINDO NOVOS TECELÕES}

Concebemos, para esta última seção, expor os resultados, mudanças e sensações que reverberaram nos entrevistados depois do envolvimento deles com as bibliotecas. O que tais práticas leitoras e informacionais significam para eles, como cada sujeito percebe a importância da biblioteca para ele e para o outro. As práticas informacionais e leitoras aqui são as experiências singulares, os desdobramentos, os efeitos, as ações em que os sujeitos se apropriam da leitura e informação. Em outros termos, o que uso da leitura, da informação e da biblioteca gera nesses indivíduos e o que eles produzem e sentem a partir disso.

A biblioteca comunitária é considerada pelos entrevistados um lugar imprescindível dentro da comunidade, que dá acesso a um grupo periférico frequentemente excluído da sociedade. Apresenta-se como um elemento essencial que faz a diferença na história do local, a ponto de a comunidade não querer que ela acabe ou se enfraqueça, pois já se sente parte da biblioteca e abraça a causa. O mediador Miguel diz:

[as bibliotecas públicas estaduais e municipais] são bibliotecas que são centrais e são bibliotecas que a população mesmo que tá nas periferias não tem acesso. Como estratégia de formação de leitores, as bibliotecas comunitárias fazem a ponte mesmo, estão na ponta desse processo de sensibilização à leitura porque estão onde o povo está (Miguel).

As bibliotecas são vistas também como espaços de socialização e convivência. Um local de estudo, de aprendizado, espaço de lazer e de cultura, isto é, "tem essa função social fundamental, tanto na questão da leitura quanto também nessa questão de facilitar a

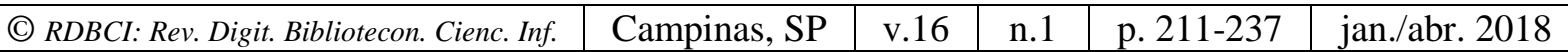


convivência entre as pessoas, contribui de certa forma também até para diminuição da violência indiretamente", pontua Miguel.

Os mediadores também percebem o progresso literário dos interagentes, a movimentação maior na biblioteca, e recebem depoimentos de pais e professores sobre a mudança de conduta como o hábito da escuta e a afetividade. Por exemplo, Augusto, e Estela, respectivamente, evocam que:

[...] Os meninos vieram em peso para fazer a carteirinha. Às vezes, a gente tá aqui e eles invadem a biblioteca. A gente percebe que depois desse projeto, o movimento cresceu, teve um resultado bem bacana. Quem lia continua lendo e quem não lia tá começando a ler. Descobri alguns poetas no meio da escola, algumas crianças que de repente até elas mesmas nem sabiam.

As escolas chegam para a gente para comentar que os próprios alunos pedem para os professores e cobram dos professores que leiam as histórias para eles e afirmam "Por que na biblioteca faz".

Também é nítida a função da biblioteca comunitária como instrumento de politização e desenvolvimento da cidadania e autonomia. Um local que, por meio da disponibilização de livros, da mediação literária e da ação cultural, vai atuando num processo de educação cidadã e suas formas de intervenção:

Eu acho que a biblioteca comunitária é esse lugar de acesso à cultura letrada, acesso a
um lugar de fortalecimento político, de exercício do discurso mesmo, da prática de
falar, do conviver. Atualmente, eu encaro as bibliotecas nesse sentido, para além
desse lugar da democratização do acesso, da democratização da informação, mas de
produzir uma informação, é um lugar de empoderação, fortalecimento (Leonardo)

Mas essa relação de estar com a biblioteca até hoje é de acreditar que isso aqui é um espaço de transformação, até um espaço mesmo de empoderamento político, humano, das pessoas estarem em um espaço como esse, de ter acesso ao livro, porque o livro no Brasil é caro (Sérgio).

O trabalho em uma biblioteca comunitária é algo desafiador que exige o constante exercício da empatia e da persistência e traz diversas possibilidades de vivências aos seus colaboradores. O conhecimento de outras histórias de vida e de outras realidades foi um fator notado como fundamental na sensibilização dessas pessoas para a compreensão e aceitação do outro.

Por fim, as pessoas que trabalham na biblioteca muitas vezes possuem a identidade confundida com a história daquele espaço, porque estão envolvidas desde o começo e acreditam nesse ideal. Conceição menciona o seguinte: "a mudança na minha vida vem de

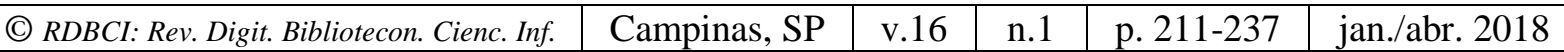


toda essa trajetória da construção da Releitura, não teve um antes e um depois porque eu me misturo também com essa história".

Fica claro, pois, o amor pelas bibliotecas e a vontade de mudança por parte desses sujeitos. A biblioteca comunitária representa um local de convivência diária entre pessoas e de contato dessas pessoas com a leitura, informação e cultura, que buscam diariamente superar o desafio da sustentabilidade para que assim possam continuar na construção de comunidades mais leitoras e críticas. As práticas leitoras e informacionais existentes nessas bibliotecas são resultados dos modos de mediação e apropriação da leitura e informação realizadas por eles, e revelam o quão significativos são esses espaços para a vida dos sujeitos.

\section{PREGANDO BOTÕES: algumas considerações}

Esta pesquisa procurou descobrir quais eram as práticas de leitura e informação desenvolvidas nas bibliotecas do coletivo Releitura-PE, tanto por meio das ações realizadas por cada biblioteca como pelas condutas, vivências e sentimentos dos sujeitos que delas fazem parte. De maneira específica, buscamos caracterizar cada uma das quatro bibliotecas, verificar quais eram as práticas de leitura e informação existentes nesses espaços, bem como compreender o que estas práticas significavam para os sujeitos.

Nesse sentido, as práticas de leitura individuais se mostraram bastante plurais, na medida em que tivemos sujeitos que se sentem felizes lendo e outros que sentem dificuldade ou angústia ao ler. Enquanto uns não conseguem viver sem ler, sendo, dessa forma, a leitura associada a um "vírus" que contagia e que permanece, outros miram no seu caráter instrumental e escolar. Dessa forma, a leitura possibilita a ampliação do universo da linguagem e do universo cultural, da mesma forma que auxilia no exercício escolar e profissional.

Foram apresentadas pelos entrevistados as diferentes formas de contato com a leitura em distintas fases da vida, bem como as referências desse processo como a família, a escola ou a livraria, biblioteca pública e a biblioteca comunitária. Os sujeitos também citaram suas maneiras de ler, suas preferências e gostos literários, assim como os significados que a leitura transmite para eles e o que é produzido ou sentido a partir dessa interação com a leitura. Sendo assim, a leitura representa uma fonte de criatividade, criticidade, diversão, alteridade e humanização, como também uma forma de se construir a si mesmo. Encontramos nesses leitores pessoas sensíveis e críticas, altamente politizadas e engajadas e, sobretudo, sonhadoras, que possuem um ideal e que buscam concretizar esse ideal individual ou coletivo.

Em relação às práticas de informação, apesar de elas terem sido tratadas diretamente em apenas uma das seções do texto, considerando o conceito amplo de informação que

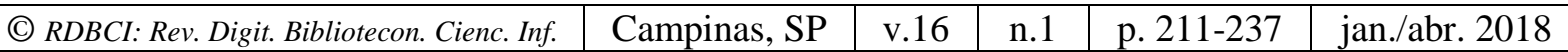


trouxemos, as práticas informacionais existentes nessas bibliotecas vão além da busca e leitura de notícias, estando presentes também nas outras ações, sobretudo, nas atividades de mediação e de comunicação e divulgação de atividades, entre outras. Todavia, ressaltamos também que o conceito de informação discutido na CI diverge bastante do conceito de informação entendido pelo público em geral, e nesta pesquisa não foi possível realizar um aprofundamento desta questão. Portanto, caberia uma exploração maior para identificar o que é informação para esses sujeitos e quais são as fontes pelas quais eles se informam e comparar esses resultados com as discussões teóricas estruturadas na CI.

Notamos que as práticas informacionais são ações essenciais desempenhadas pelos sujeitos entrevistados quando estes recorrem ao ato de se informar sobre um variado conteúdo de informações para se manterem atuantes em suas funções e atualizados das coisas que ocorrem à sua volta. Além dos processos de busca e uso da informação mediante um processo de mediação e apropriação informacional, os entrevistados também registram e partilham informações que são produzidas por meio de suas ações individuais e coletivas nas bibliotecas através das formas de comunicação e divulgação de atividades, sobretudo por meio de práticas escritas e orais. Além disso, não concebem o ato de se informar como algo ingênuo ou passivo, mas procuram atuar de modo ativo na seleção de fontes de informação que sejam condizentes com suas perspectivas políticas e históricas tentando se manter críticos em meio ao processo manipulador midiático e ao mesmo tempo demonstrando uma postura criativa diante deste cenário.

Concebemos, portanto, de uma maneira não linear, que foram e são essas práticas de leitura e informação que impulsionaram esses sujeitos a interagir com essas bibliotecas comunitárias na criação dos espaços e no desenvolvimento das ações cotidianas, incluindo a criação da Releitura e o agenciamento de parcerias.

Sobre isso, as práticas leitoras e informacionais dessas bibliotecas estão vinculadas também à participação política da Releitura no que tange às práticas de incidência política desempenhadas por este coletivo no cenário pernambucano. Isto pode ser observado quando a Releitura atua no planejamento de formas de sustentabilidade das bibliotecas, bem como na participação nos debates sobre políticas públicas para a intervenção nas propostas de orçamentos públicos destinados ao livro, leitura e bibliotecas e, consequente, formulação de políticas que garantam o desenvolvimento de suas atividades.

Além disso, as atividades realizadas nessas bibliotecas retratam seu caráter criativo de desenvolver ações que sejam características das comunidades, visando a estreitar os vínculos com o público e articulando formas inventivas de intervenção em tais locais. As práticas de mediação de leitura e ações culturais representam, portanto, uma forma de manter vivo o acervo e os traços identitários e culturais dessas populações, de modo fazer com que eles mesmos construam suas singularidades por meio de práticas escritas e artísticas.

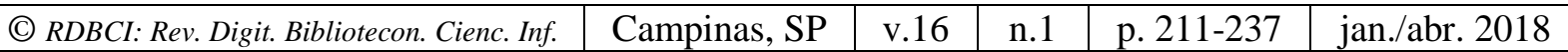


Desse modo, os avanços alcançados pela Releitura de bibliotecas são grandes e jamais imaginados pelos seus integrantes. Todavia, devido aos percalços apresentados pelo cenário político e social configurado no país, acreditamos que a ampliação das parcerias e a elaboração de novas formas de sustentabilidade devam ser angariadas com cada vez mais intensidade e articulação, bem como as estratégias de comunicação devam ser mais incisivas e consistentes para que o coletivo consiga permanecer e conquistar novos espaços, novas comunidades e novos leitores.

Por fim, deixamos aqui nosso reconhecimento e admiração a essas pessoas que trabalham nas bibliotecas comunitárias, pois são incansáveis no seu ofício de mediadores de leitura, já que abriram e abrem mão de muitos desejos pessoais em prol do benefício do outro e da causa leitora. Nem tudo o que foi dito por eles pôde ser analisado, mas fica nítido o esforço cotidiano de todos em, a todo o momento, buscarem alternativas e procurarem caminhos para que a leitura esteja viva nas comunidades. São, pois, costureiros que têm o livro como agulha e a leitura como linha, para assim construírem mais redes leitoras e continuarem nesse movimento de existência e resistência, mas nunca de desistência.

\section{REFERÊNCIAS}

ALMEIDA JÚNIOR, O. F. Competência em Informação: algumas considerações críticas. 2016. Disponível em: <http://www.ofaj.com.br/colunas_conteudo.php?cod=966>. Acesso em: 15 jan. 2017.

Bibliotecas públicas e alternativas: bibliografia comentada. Revista Brasileira de Biblioteconomia e Documentação, São Paulo, v. 26, n.1/2, p.115-127, jan./jun.1993.

Disponível em:

<http://www.brapci.inf.br/_repositorio/2011/10/pdf_a725a4bdc0_0019248.pdf>. Acesso em: 06 jun. 2015

Leitura, mediação e apropriação da informação. In: SANTOS, J.P. (Org.). A leitura como prática pedagógica na formação do profissional da informação. Rio de Janeiro: Biblioteca Nacional, 2007. p. 33-45.

Mediação da Informação e Múltiplas Linguagens. Tendências da Pesquisa Brasileira em Ciência da Informação, v. 2, p. 89-103, 2009.

.; BORTOLIN, S. Mediação da informação e da leitura. In: SILVA, T. E. (Org.). Interdisciplinaridade e transversalidade em Ciência da Informação. Nectar, Recife, v. 1, p. 67-86, 2008.

ALMEIDA, M. A. A informação, seus personagens e histórias. InCID: R. Ci. Inf. e Doc., Ribeirão Preto, v. 6, n. 1, p. 116-119, mar./ago. 2015. Resenha de: GLEICK, James. A

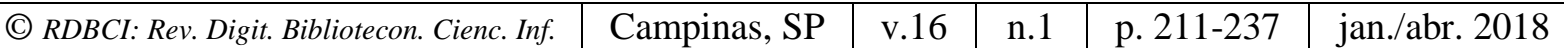


informação: uma história, uma teoria, uma enxurrada. São Paulo: Companhia das Letras, 2013.

ARAÚJO, C. A. A. Teoria matemática da comunicação e a questão da interdisciplinaridade. Revista Cesumar Ciências Humanas e Sociais Aplicadas, v.16, n. 2, p. 545-570, set./dez. 2011.

BARDIN, L. Análise de conteúdo. Lisboa: Edições 70, 2008.

BARRETO, A. A. A condição da informação. São Paulo em Perspectiva, v. 16, n. 3, p. 6774, 2002.

BERGER, P.; LUCKMANN, T. A construção social da realidade: tratado de sociologia do conhecimento. 36. ed. Petrópolis, RJ: Vozes, 2014.

BUCKLAND, M. Information as thing. Journal of the American Society of Information Science, v. 42, n. 5, p. 351-360, 1991.

CÂNDIDO, A. Direito à Literatura. In: LIMA, A. de et al. O Direito à

Literatura. Recife: Ed. Universitária da UFPE, 2012. p. 17-40.

CAPURRO, R. Epistemologia e ciência da informação. In: ENCONTRO NACIONAL DE PESQUISA EM CIÊNCIA DA INFORMAÇÃO, 5, 2003, Belo Horizonte. Anais... Belo Horizonte, MG: Associação Nacional de Pesquisa e Pós-Graduação em Ciência da Informação e Biblioteconomia, 2003. 1 CD-ROM.

CAPURRO, R.; HJØRLAND, B. O conceito de informação. Perspectivas em Ciência da Informação, Belo Horizonte, v. 12, n. 1, p. 148-207, jan./abr. 2007.

COSSON, R. Círculos e leitura e letramento literário. São Paulo: Contexto, 2014

CUNHA, M. B.; AMARAL, S. A.; DANTAS, E. B. Manual de estudo de usuários da informação. São Paulo: Atlas, 2015.

FERNANDEZ, M. A. A.; MACHADO, E. Bibliotecas públicas: um equipamento cultural para o desenvolvimento local: guia político-pedagógico para ampliação do número de bibliotecas públicas no Brasil. Recife: Centro de Desenvolvimento e Cidadania, 2016.

FREIRE, P. A importância do ato de ler: em três artigos que se completam. 51. ed. São Paulo: Cortez, 2011.

GUARALDO, T. S. B. Práticas de informação e leitura: a mediação leitor e jornal na leitura diária. 2012. 240f. Tese (Doutorado em Ciência da Informação) - Universidade Estadual Paulista Júlio de Mesquita Filho, São Paulo, 2012.

MACHADO, E. C. Bibliotecas comunitárias como prática social no Brasil. 2008. 184f. Tese (Doutorado em Ciência da Informação) - Programa de Pós-Graduação em Ciência da Informação, Universidade de São Paulo, 2008.

MARTINS, M. H. O que é leitura. São Paulo: Brasiliense, 1997.

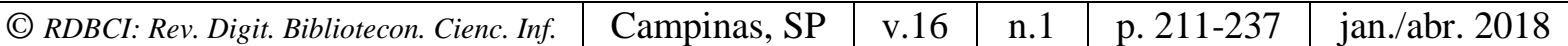


NEITZEL, A. A; BRIDON, J.; WEISS, C. S. Mediações em leitura: encontros na sala de aula. Rev. bras. Estud. pedagog., Brasília, v. 97, n. 246, p. 305-322, mai./ago. 2016.

PETIT, M. Os jovens e a leitura: uma nova perspectiva. São Paulo: Editora 34, 2008.

RELEITURA BIBLIOTECAS EM REDE: fortalecendo conexões leitoras. Projeto submetido ao Prêmio Viva Leitura. Recife, 2014. Disponível em:

<www.premiovivaleitura.org.br/projetos_uploads/22112014101625.doc>. Acesso em: 05 abr. 2016.

RELEITURA. Bibliotecas comunitárias em rede: para tecer os futuros nas teias da literatura e da criatividade. [2013]. 1 folder. Apoio Instituto C\&A, Centro de Estudos em Educação e Linguagem e Centro de Cultura Luiz Freire.

RITER, C. A formação do leitor literário em casa e na escola. São Paulo: Biruta, 2009.

SAVOLAINEN, R. Information behavior and information practice: reviewing the "umbrella concepts" of information-seeking studies. Library Quarterly, v. 77, n. 2, p. 109-132, 2007.

SAVOLAINEN, R. Everyday information practices: a social phenomenological perspective. Lanham, MD:Scarecrow Press, 2008.

SILVA, A.; NUNES, J. Práticas informacionais como paradigma: por uma teoria social da informação. In: ENCONTRO NACIONAL DE PESQUISA EM CIÊNCIA DA

INFORMAÇÃO, 15, 2013, Belo Horizonte. Anais... Belo Horizonte, MG: ECI, UFMG. 1 CD-ROM.

WERSIG, Gernot; NEVELING, Ulrich. Os fenômenos de interesse para a ciência da informação. Texto publicado originalmente em inglês no Periódico Information Scientist, v.9, n.4, p.127-140, dec., 1975. Disponível em:

<http://www.alvarestech.com/lillian/GestaoDaInformacao/Rogerio/WersigNeveling.pdf $>$. Acesso em: 23 jan. 2016.
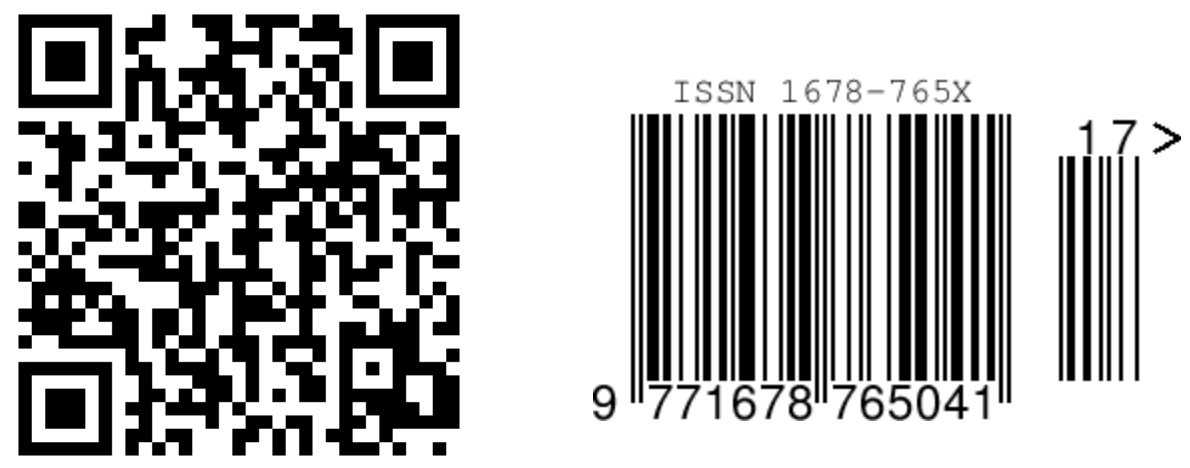

(C) RDBCI: Rev. Digit. Bibliotecon. Cienc. Inf. 